\title{
Anopheles bionomics, insecticide resistance mechanisms, and malaria transmission in the Korhogo area, northern Côte d'Ivoire: a pre-intervention study
}

Barnabas Zogo ${ }^{1,2,3, *}$, Dieudonné Diloma Soma ${ }^{4,5}$, Bertin N'Cho Tchiekoi ${ }^{1}$, Anthony Somé ${ }^{4}$, Ludovic P. Ahoua Alou ${ }^{1}$, Alphonsine A. Koffi ${ }^{1}$, Florence Fournet ${ }^{2}$, Amal Dahounto ${ }^{2}$, Baba Coulibaly ${ }^{1,2}$, Souleymane Kandé ${ }^{1}$, Roch Kounbobr Dabiré ${ }^{4}$, Lamine Baba-Moussa ${ }^{3}$, Nicolas Moiroux ${ }^{2,4}$, and Cédric Pennetier ${ }^{1,2}$

${ }^{1}$ Institut Pierre Richet (IPR), Institut National de Santé Publique (INSP), BP 1500 Bouaké, Côte d'Ivoire

2 Maladies Infectieuses et Vecteurs : Ecologie, Génétique, Evolution et Contrôle (MIVEGEC), Univ Montpellier, CNRS, IRD, BP 64501, Montpellier, France

${ }^{3}$ Faculté des Sciences et Techniques (FAST), Université d'Abomey-Calavi, BP 1604, Cotonou, Benin

${ }^{4}$ Institut de Recherche en Sciences de la Santé (IRSS), BP 545, Bobo Dioulasso, Burkina Faso

${ }^{5}$ Institut Supérieur des Sciences de la Santé, Université Nazi Boni, BP 1091, Bobo-Dioulasso, Burkina Faso

Received 29 March 2019, Accepted 21 June 2019, Published online 12 July 2019

\begin{abstract}
A better understanding of malaria transmission at a local scale is essential for developing and implementing effective control strategies. In the framework of a randomized controlled trial (RCT), we aimed to provide an updated description of malaria transmission in the Korhogo area, northern Côte d'Ivoire, and to obtain baseline data for the trial. We performed human landing collections (HLCs) in 26 villages in the Korhogo area during the rainy season (September-October 2016, April-May 2017) and the dry season (November-December 2016, February-March 2017). We used PCR techniques to ascertain the species of the Anopheles gambiae complex, Plasmodium falciparum sporozoite infection, and insecticide resistance mechanisms in a subset of Anopheles vectors. Anopheles gambiae s.l. was the predominant malaria vector in the Korhogo area. Overall, more vectors were collected outdoors than indoors $(p<0.001)$. Of the 774 An. gambiae s.l. tested in the laboratory, $89.65 \%$ were An. gambiae s.s. and $10.35 \%$ were An. coluzzii. The frequencies of the $k d r$ allele were very high in An. gambiae s.s. but the ace- 1 allele was found at moderate frequencies. An unprotected individual living in the Korhogo area received an average of 9.04, 0.63, 0.06 and 0.12 infected bites per night in September-October, November-December, February-March, and April-May, respectively. These results demonstrate that the intensity of malaria transmission is extremely high in the Korhogo area, especially during the rainy season. Malaria control in highly endemic areas such as Korhogo needs to be strengthened with complementary tools in order to reduce the burden of the disease.
\end{abstract}

Key words: Malaria, Vectors, Resistance, Intensity of transmission.

Résumé - Bionomique des Anophèles, mécanismes de résistance aux insecticides et transmission du paludisme dans la région de Korhogo, dans le nord de la Côte d'Ivoire : une étude pré-intervention. Une meilleure connaissance de la transmission du paludisme à l'échelle locale est essentielle pour élaborer et mettre en œuvre des stratégies de lutte efficaces. Dans le cadre d'un essai contrôlé randomisé, nous avons pour objectifs de fournir une description actualisée de la transmission du paludisme dans la zone de Korhogo, au nord de la Côte d'Ivoire, et de collecter les données de base pour l'essai. Nous avons capturé les moustiques sur des volontaires humains dans 26 villages de la zone de Korhogo pendant la saison pluvieuse (septembre-octobre 2016, avril-mai 2017) et la saison sèche (novembre-décembre 2016, février-mars 2017). À l'aide des techniques de PCR, nous avons déterminé les espèces au sein du complexe Anopheles gambiae, les infections par Plasmodium falciparum au stade sporozoïte et les mécanismes de résistance aux insecticides dans un sous-échantillon d'anophèles vecteurs. Anopheles gambiae s.l. est de loin le vecteur majoritaire du paludisme dans la zone de Korhogo. Au total, plus de vecteurs ont été collectés à l'extérieur des habitations qu'à l'intérieur $(p<0.001)$. Des 774 An. gambiae s.l. analysés au laboratoire, $89,65 \%$ étaient An. gambiae s.s. et 10,35\% An. coluzzii. Les fréquences alléliques du gène $k d r$ étaient très élevées chez An. gambiae s.s. alors que les fréquences alléliques du gène ace-l étaient modérées. Une personne non protégée vivant à Korhogo reçoit chaque nuit en moyenne 9,04 piqûres infectantes (pi) en septembre-octobre, 0,63

\footnotetext{
*Corresponding author: barnabas.zogo@ird.fr
}

This is an Open Access article distributed under the terms of the Creative Commons Attribution License (http://creativecommons.org/licenses/by/4.0), which permits unrestricted use, distribution, and reproduction in any medium, provided the original work is properly cited. 
pi en novembre-décembre, 0,06 pi en février-mars et 0,12 pi en avril-mai. Ces résultats démontrent que l'intensité de la transmission du paludisme est très élevée dans la zone de Korhogo, particulièrement en saison pluvieuse. La lutte contre le paludisme dans les zones de forte endémicité comme Korhogo doit être renforcée par des outils complémentaires afin de réduire le fardeau de la maladie.

\section{Introduction}

Malaria parasites are transmitted to humans by infected female mosquitoes of the genus Anopheles, which comprises more than 500 species. About 70 of these species are reported to be vectors of human malaria parasites [38]. The intensity of malaria transmission is exceptionally high in Africa, largely because of the high vectorial capacity of the major vector species, namely Anopheles gambiae s.s., Anopheles coluzzii, Anopheles arabiensis, and Anopheles funestus s.s. These species display strong anthropophilic host-seeking behavior, and have a long life expectancy, and therefore cause large numbers of secondary malaria cases from one infected individual [41]. The entomological inoculation rate (EIR) that represents the average number of infected bites per person per unit time is generally used to measure the intensity of malaria transmission [39]. The EIR in Africa varies greatly between countries and even within small geographical areas [35]. This heterogeneity needs to be considered when planning and implementing vector control strategies.

Long-lasting insecticidal nets (LLINs) are the main vector control tool used in Côte d'Ivoire to reduce malaria transmission [41]. They are developed to provide physical and chemical barriers against vectors which enter houses to bite humans at night [21]. Consequently, the effectiveness of LLINs may depend on parameters such as the susceptibility of vectors to pyrethroids and their biting behavior. Unfortunately, resistance to the four insecticide classes used for public health (pyrethroids, organochlorines, carbamates, and organophosphates) is common in the main malaria vector species across Côte d'Ivoire [6, 24, 36, 43]. This resistance involves multiple mechanisms such as metabolic and target site resistance. $K d r$ (responsible for dichlorodiphenyltrichloroethane and pyrethroid resistance) and ace-1 mutations (responsible for organophosphate and carbamate resistance) are widespread, but are found at variable frequencies across the country [6, 24, 36, 43]. However, there is very little recent information on the biting behavior of malaria vector species in many areas of Côte d'Ivoire. Studies in several settings across Africa have shown changes in vector biting behaviors by feeding either mainly outdoors, or in the early morning or in the early evening to avoid contact with insecticide-based tools [14, 29, 32].

Understanding malaria transmission at a local scale by determining the main malaria vector species, their abundance, biting behavior, frequencies of insecticide resistance alleles, and EIRs is a prerequisite for developing and implementing effective control and elimination strategies. The present study was conducted as part of a randomized controlled trial (RCT) in the framework of a project called REACT. The project, which was conducted in 26 villages in northern Côte d'Ivoire (Korhogo area) and 27 villages in southwestern Burkina Faso (Diébougou area), was designed to investigate whether the use of vector control strategies in combination with long-lasting insecticidal mosquito nets in areas with intense pyrethroid-resistance provides additional protection against malaria. In this study, we present the results of one year of entomological investigations in the villages of the Korhogo area in Côte d'Ivoire, with the aim of providing an updated description of malaria transmission and obtaining baseline data for the trial. A preprint of this work was published on March 28, 2019 [42].

\section{Materials and methods Study area}

The study area included 26 villages of the department of Korhogo (between $9^{\circ} 10^{\prime}$ and $9^{\circ} 40^{\prime} \mathrm{N}$ and between $5^{\circ} 20^{\prime}$ and $\left.5^{\circ} 60^{\prime} \mathrm{W}\right)$ located in northern Côte d'Ivoire, West Africa (Fig. 1). The villages were selected based on an average population size of 300 inhabitants, a distance between two villages of at least $2 \mathrm{~km}$, and accessibility during the rainy season. The Korhogo area is characterized by a Sudanese climate with a unimodal rainfall regimen from May to November. The annual rainfall varies from 1200 to $1400 \mathrm{~mm}$, while the mean annual temperature ranges from 21 to $35^{\circ} \mathrm{C}$. The minimum temperatures can drop to $16^{\circ} \mathrm{C}$ due to the Harmattan wind during December and January. The natural vegetation is mainly a mixture of savannah and open forest characterized by trees and shrubs that are approximately $8-15 \mathrm{~m}$ in height. The Korhogo area is fed by tributaries of the Bandama River such as the Naramou and Solomougou rivers, which dry up in the dry season. Nevertheless, the area has a high density of water dams that allow agriculture to be practiced throughout the year [17]. Therefore, in areas where the soil is highly conducive to agriculture, most of the local inhabitants are farmers and their staple crops include rice, maize, and cotton. Rice is mainly cultivated during the rainy season in flooded soils although it is also occasionally planted in the dry season in irrigated areas in the vicinity of dams. The main malaria vector control intervention in Korhogo is LLINs which are freely distributed by the government every 3-4 years [33]. The last distribution before this study was performed in 2014. According to surveys conducted within the framework of the REACT project, the mean proportion of households with at least one Insecticide Treated Net (ITN) for every two people in the area was $24 \%$ in 2016 . Indoor residual spraying and larviciding have so far not been implemented in Côte d'Ivoire.

\section{Mosquito sampling}

We performed human landing collections (HLCs) in the 26 villages during four surveys: two in the rainy season (from September 21 to October 10, 2016 and from April 11 to April 29,2017 ), and two in the dry season (from November 18 to December 6, 2016 and February 14 to March 04, 2017). 


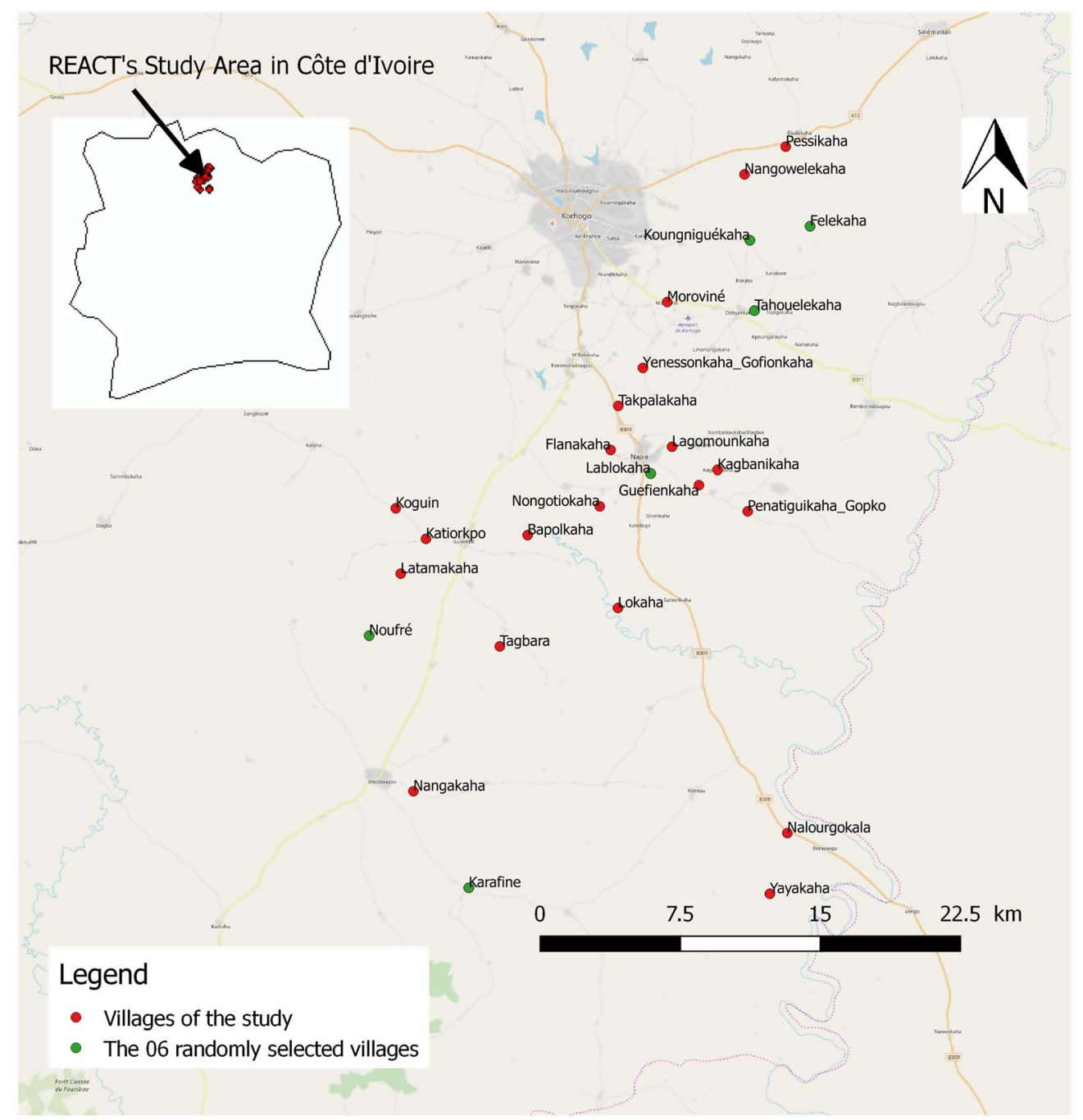

Figure 1. Map of the study area.

In each village, we collected host-seeking mosquitoes during one night per survey from 17:00 to 09:00 in four randomly selected houses. Each selected house had one collector indoors and one collector outdoors. They were rotated between indoor and outdoor collection sites every hour at each selected house to reduce potential collector bias. Collectors were organized into two teams of eight persons in each village; the first group collected from 17:00 to 01:00 and the second from 01:00 to 09:00. Each night of collection, one technician from the Institut Pierre Richet (IPR) assisted by two local supervisors supervised the mosquito collections in each village to ensure that they were performed properly. The details of the indicators used for quality control are given in Supplementary material.

\section{Anopheles vector processing}

After collections, we morphologically identified in the field all the mosquitoes to species or species complex level according to established taxonomic keys $[16,17]$. Only Anopheles spp. mosquitoes were kept and were stored individually in labeled tubes with silica gel at $-20^{\circ} \mathrm{C}$ for molecular analysis. Due to the very large numbers of vectors collected, we analyzed in the laboratory a subsample of Anopheles spp. vectors from six villages (Tahouelékaha, Koungniguékaha, Lablokaha, Felékaha, Noufré, and Karafiné) randomly chosen out of the 26 villages included in the study (Fig. 1). From the vectors collected in these six villages, we randomly selected one individual of Anopheles gambiae s.l. per hour per collection site during each survey. We analyzed all the Anopheles nili complex individuals and all the members of the Funestus Group collected in the six villages. We extracted DNA from the head and thorax of each specimen of the subsample using the Livak method [25]. We identified sibling species of the Anopheles gambiae complex by polymerase chain reaction (PCR) [13, 37]. Quantitative PCR (qPCR) was performed to investigate the presence of $k d r$ L1014F and ace-1 G119S mutations in the individuals belonging to the Anopheles gambiae complex [2, 12], and to screen all the selected Anopheles spp. mosquitoes for Plasmodium falciparum sporozoite infection [4].

\section{Ethics approval}

Ethical clearance for the study was granted by the national ethics committee (No. 063/MSHP/CNER-kp). We received 
Table 1. Diversity and abundance of mosquito species in the 26 villages in the Korhogo area during the four surveys.

\begin{tabular}{|c|c|c|c|c|c|}
\hline \multirow[t]{2}{*}{ Mosquito species } & \multicolumn{5}{|c|}{ Number of individual mosquitoes collected per survey } \\
\hline & September-October 2016 & November-December 2016 & February-March 2017 & April-May 2017 & Total \\
\hline Anopheles gambiae s.l. & 24,831 & 1344 & 289 & 2314 & 28,778 \\
\hline Anopheles funestus group & 458 & 11 & 0 & 0 & 469 \\
\hline Anopheles nili complex & 75 & 96 & 0 & 6 & 177 \\
\hline Anopheles pharoensis & 35 & 1 & 1 & 2 & 39 \\
\hline Anopheles ziemanni & 8 & 2 & 0 & 0 & 10 \\
\hline Anopheles coustani & 6 & 1 & 0 & 0 & 7 \\
\hline Aedes aegypti & 18 & 14 & 4 & 18 & 54 \\
\hline Aedes africanus & 4 & 0 & 0 & 0 & 4 \\
\hline Aedes furcifer & 3 & 0 & 0 & 0 & 3 \\
\hline Aedes hirsutus & 1 & 0 & 0 & 0 & 1 \\
\hline Aedes luteocephalus & 37 & 0 & 0 & 0 & 37 \\
\hline Aedes vittatus & 2 & 0 & 0 & 0 & 2 \\
\hline Culex annuloris & 8 & 0 & 0 & 0 & 8 \\
\hline Culex antennatus & 9 & 6 & 15 & 78 & 108 \\
\hline Culex cinereus & 119 & 0 & 3 & 0 & 122 \\
\hline Culex decens & 4 & 3 & 2 & 0 & 9 \\
\hline Culex ingrami & 180 & 71 & 40 & 35 & 326 \\
\hline Culex nebulosus & 21 & 1 & 1 & 51 & 74 \\
\hline Culex quinquefasciatus & 8 & 0 & 0 & 3 & 11 \\
\hline Culex tigripes & 2 & 0 & 0 & 0 & 2 \\
\hline Mansonia africana & 221 & 149 & 27 & 5 & 402 \\
\hline Mansonia uniformis & 126 & 549 & 5 & 0 & 680 \\
\hline Uranotaenia balfouri & 0 & 1 & 0 & 0 & 1 \\
\hline Total & 26,176 & 2249 & 387 & 2512 & 31,324 \\
\hline
\end{tabular}

Table 2. Anopheles gambiae complex species in a subset analyzed.

\begin{tabular}{|c|c|c|c|}
\hline \multirow[t]{2}{*}{ Survey } & \multirow[t]{2}{*}{ Species } & \multicolumn{2}{|c|}{ Number of individuals analyzed } \\
\hline & & Indoor $(\%)$ & Outdoor $(\%)$ \\
\hline \multirow[t]{2}{*}{ September-October } & Anopheles gambiae s.s. & $197(96.10)$ & $211(99.06)$ \\
\hline & Anopheles coluzzii & $8(3.90)$ & $2(0.94)$ \\
\hline \multirow[t]{2}{*}{ November-December } & Anopheles gambiae s.s. & $74(96.10)$ & $86(97.73)$ \\
\hline & Anopheles coluzzii & $3(3.90)$ & $2(2.27)$ \\
\hline \multirow{2}{*}{ February-March } & Anopheles gambiae s.s. & $19(63.33)$ & $24(61.54)$ \\
\hline & Anopheles coluzzii & $11(36.67)$ & $15(38.46)$ \\
\hline \multirow[t]{3}{*}{ April-May } & Anopheles gambiae s.s. & $24(54.55)$ & $32(66.67)$ \\
\hline & Anopheles coluzzii & $20(45.45)$ & $16(33.33)$ \\
\hline & Anopheles gambiae s.s. & $314(88.20)$ & $353(90.98)$ \\
\hline \multirow[t]{2}{*}{ Total } & Anopheles coluzzii & $42(11.80)$ & $35(9.02)$ \\
\hline & Total & 356 & 388 \\
\hline
\end{tabular}

community agreement before the beginning of the study, and we obtained written informed consent from all the mosquito collectors and supervisors. Yellow fever vaccines were administered to all the field staff. Collectors were treated free of charge when they were diagnosed with malaria during the study period. They were also free to withdraw from the study at any time without any consequences.

\section{Data analysis}

The human biting rate (HBR) for all malaria vector species was calculated as the number of Anopheles vectors (An. gambiae s.l., An. funestus group, An. nili complex) collected per person per night. The P. falciparum sporozoite rate (SR) in each vector species population was calculated as the number of vectors positive for sporozoites over the number of vectors tested. For each survey, the daily EIR was calculated by multiplying the mean HBR for all malaria vector species by the $P$. falciparum $\mathrm{SR}$ in all malaria vector species. Statistical analyses were performed using R software [34].

In order to compare HBRs between surveys and between collection positions (indoors or outdoors), we analyzed counts of Anopheles vectors (all species) using a negative binomial mixed effect model (function "glmer" from the package lme4) [5]. The fixed variables were the survey, the collection position (indoors/outdoors), and their interaction. Villages and collection houses were used as random intercepts. 
A

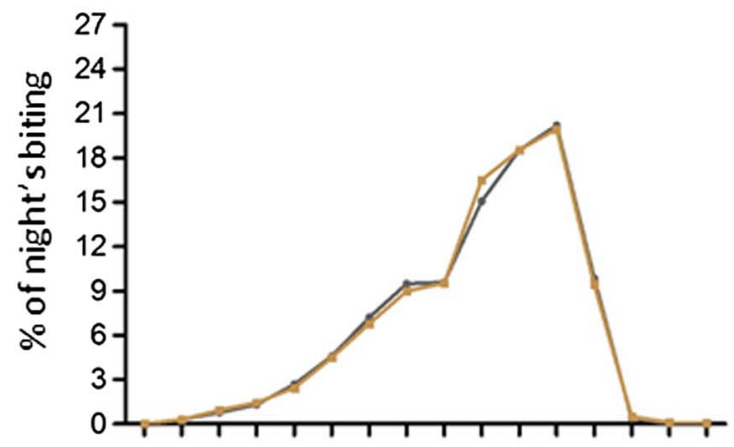

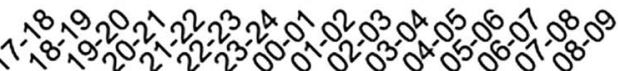

$\mathrm{C}$

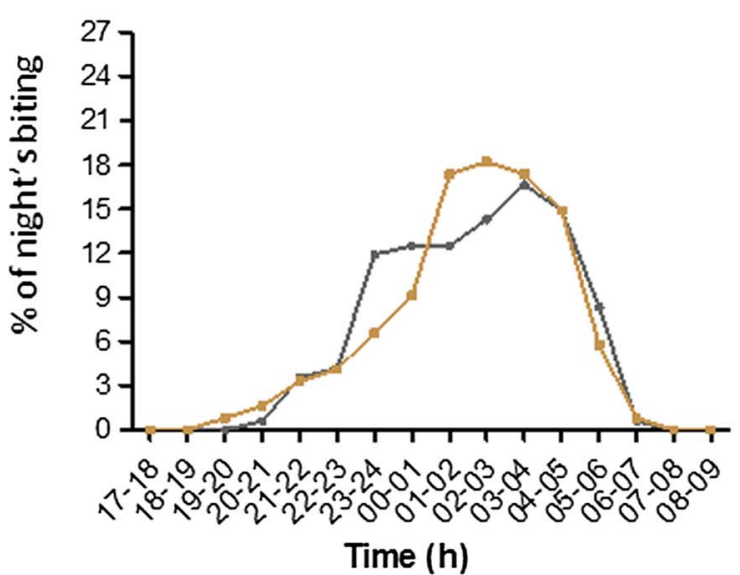

B
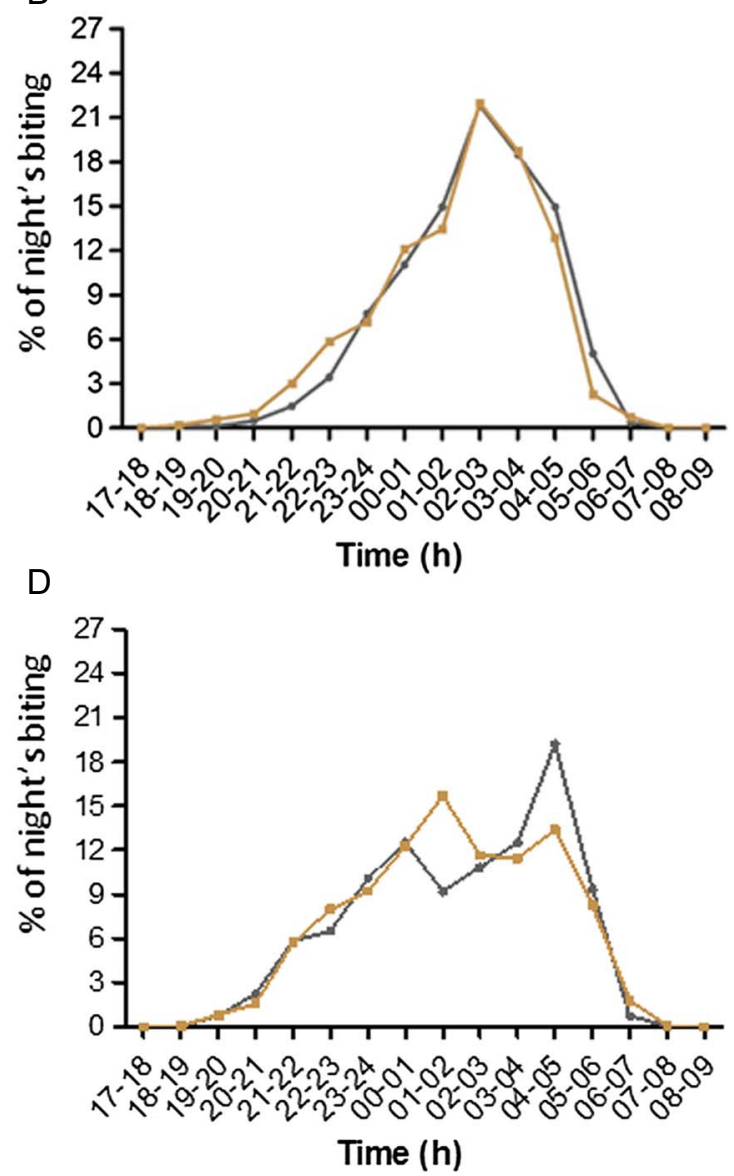

$\rightarrow$ Outdoor $\rightarrow$ Indoor

Figure 2. Mean hourly biting activity profiles of Anopheles gambiae s.l. mosquitoes in September-October 2016 (A), November-December 2016 (B), February-March 2017 (C), and April-May 2017 (D).

We compared the SR between surveys, species, and collection positions (indoors/outdoors) using a binomial mixed effect model (function "glmer" from the package lme4). The fixed variables were the surveys, the Anopheles species, and the collection position (indoors/outdoors). Villages were set as random intercepts.

For both the HBR and SR models, we performed backward stepwise deletion of the fixed terms followed by likelihood ratio tests. We used the Tukey's post-hoc test to compare Anopheles counts among surveys according to the final model. Rates ratios, odds ratios and their $95 \%$ confidence intervals were computed.

In order to compare night biting activity profiles of $A n$. gambiae s.l. among surveys, we compared the distribution of collection times using a Kruskal-Wallis rank sum test, followed by a multiple comparison Dunn's post-hoc test.

We used the G-test [18] implemented in GenePOP 4.7 and run in R [15] to compare gene frequencies at the $k d r$ and ace-1 loci between An. gambiae s.s. and An. coluzzii, among surveys, and among villages [34]. We tested the distribution of genotypes at the $k d r$ and ace-1 loci for conformity to HardyWeinberg equilibrium within both species of the An. gambiae complex, in each survey, and in each village, using exact tests as implemented in GenePOP [34].

\section{Results}

We collected a total of 31,324 female mosquitoes belonging to 5 genera (Anopheles, Culex, Aedes, Mansonia, and Uranotaenia), and 23 species or species complexes/groups in the 26 villages during the four surveys. Anopheles gambiae s.l. represented a large proportion of the mosquito species collected, accounting for $94.86 \%, 59.76 \%, 74.68 \%$, and $92.12 \%$ of the total collected in September-October 2016, November-December 2016, February-March 2017 and April-May 2017, respectively. All the mosquitoes identified as members of the Funestus Group and the An. nili complex represented less than $2 \%$ of the total mosquitoes collected (Table 1). Speciation was successful for $97 \%$ of the 764 An. gambiae s.l. genotyped to species by PCR. Out of the 356 An. gambiae s.l. collected indoors and successfully tested, $314(88.20 \%)$ were $\mathrm{An}$. gambiae s.s., and $42(11.80 \%)$ were $\mathrm{An}$. coluzzii. Of the $388 \mathrm{An}$. gambiae s.l. collected outdoors and successfully tested, 353 (90.98\%) were An. gambiae s.s., and $35(9.02 \%)$ were $A n$. coluzzii. In total, $89.65 \%$ of An. gambiae s.l. collected and successfully tested were An. gambiae s.s., and $10.35 \%$ were $A n$. coluzzii (Table 2).

The mean HBR for all malaria vector species (An. gambiae s.l., Funestus Group, An. nili complex) in the study area was 
Table 3. Plasmodium falciparum sporozoite rates in a subset of Anopheles vectors according to taxonomic groups.

\begin{tabular}{|c|c|c|c|c|}
\hline Survey & Species, group or complex & No. positive for $\mathrm{Pf}$ & No. tested & SR (\%) $[95 \% \mathrm{CI}]$ \\
\hline \multirow[t]{5}{*}{ September-October 2016} & Anopheles gambiae s.s. & 29 & 408 & $7.14[5.02-10.07]$ \\
\hline & Anopheles coluzzii & 1 & 10 & $10.00[0.51-40.42]$ \\
\hline & Funestus Group & 8 & 47 & $17.02[8.89-30.14]$ \\
\hline & Anopheles nili complex & 1 & 63 & $1.59[0.08-8.46]$ \\
\hline & Total & 39 & 528 & $7.39[5.45-9.94]$ \\
\hline \multirow[t]{5}{*}{ November-December 2016} & Anopheles gambiae s.s. & 14 & 160 & $8.75[5.28-14.15]$ \\
\hline & Anopheles coluzzii & 1 & 5 & $20.00[1.03-62.45]$ \\
\hline & Funestus Group & 0 & 1 & $0.00[0.00-94.87]$ \\
\hline & Anopheles nili complex & 0 & 1 & $0.00[0.00-94.87]$ \\
\hline & Total & 15 & 167 & $8.98[5.52-14.29]$ \\
\hline \multirow[t]{5}{*}{ February-March 2017} & Anopheles gambiae s.s. & 3 & 43 & $6.98[2.40-18.61]$ \\
\hline & Anopheles coluzzii & 0 & 26 & $0.00[0.00-12.87]$ \\
\hline & Funestus Group & - & 0 & - \\
\hline & Anopheles nili complex & - & 0 & - \\
\hline & Total & 3 & 69 & $4.35[1.49-12.02]$ \\
\hline \multirow[t]{5}{*}{ April-May 2017} & Anopheles gambiae s.s. & 0 & 55 & $0.00[0.00-6.53]$ \\
\hline & Anopheles coluzzii & 1 & 36 & $2.78[0.14-14.17]$ \\
\hline & Funestus Group & - & 0 & - \\
\hline & Anopheles nili complex & - & 0 & - \\
\hline & Total & 1 & 91 & $1.10[0.06-5.96]$ \\
\hline
\end{tabular}

No.: number of mosquitoes; Pf: Plasmodium falciparum; SR: Sporozoite rate; [95\% CI]: 95\% Wilson’s confidence interval.

Table 4. Plasmodium falciparum sporozoite rates in a subset of Anopheles vectors according to locations (indoors and outdoors).

\begin{tabular}{lcccc}
\hline & Location & No. positive & No. tested & SR (\%) [95\% CI] \\
\hline September-October & Indoor & 17 & 238 & $7.14[4.51-11.14]$ \\
& Outdoor & 22 & 290 & $7.59[5.06-11.22]$ \\
November-December & Total & $\mathbf{3 9}$ & $\mathbf{5 2 8}$ & $7.39[\mathbf{5 . 4 5}-\mathbf{9 . 9 4}]$ \\
& Indoor & 7 & 90 & $9.09[4.47-17.60]$ \\
& Outdoor & 8 & $\mathbf{1 6 7}$ & $8.89[4.57-16.57]$ \\
February-March & Total & $\mathbf{1 5}$ & 30 & $\mathbf{8 . 9 8}[\mathbf{5 . 5 2 - 1 4 . 2 9 ]}$ \\
& Indoor & 2 & 39 & $6.67[1.85-21.32]$ \\
April-May & Outdoor & 1 & $\mathbf{6 9}$ & $2.56[0.13-13.18]$ \\
& Total & $\mathbf{3}$ & 44 & $\mathbf{4 . 3 5}[\mathbf{1 . 4 9 - 1 2 . 0 2 ]}$ \\
& Indoor & 0 & 47 & $0.00[0.00-8.03]$ \\
& Outdoor & 1 & $\mathbf{9 1}$ & $2.13[0.11-11.11]$ \\
& Total & $\mathbf{1}$ & $\mathbf{1 . 1 0}[\mathbf{0 . 0 6}-\mathbf{5 . 9 6}$ \\
\hline
\end{tabular}

No.: number of mosquitoes; SR: Sporozoite rate; [95\% CI]: 95\% Wilson’s confidence interval.

Table 5. $K d r$ mutation frequencies in a subset of Anopheles gambiae s.l.

\begin{tabular}{|c|c|c|c|c|c|c|}
\hline & & RR & RS & SS & Total & Allelic frequency $(\%)[95 \% \mathrm{CI}]$ \\
\hline \multirow{2}{*}{ September-October } & Anopheles gambiae s.s. & 402 & 1 & 0 & 403 & 99.88 [99.30-99.99] \\
\hline & Anopheles coluzzii & 9 & 1 & 0 & 10 & 95 [76.39-99.74] \\
\hline \multirow{2}{*}{ November-December } & Anopheles gambiae s.s. & 160 & 0 & 0 & 160 & $100[98.81-100]$ \\
\hline & Anopheles coluzzii & 5 & 0 & 0 & 5 & $100[72.25-100]$ \\
\hline \multirow[t]{2}{*}{ February-March } & Anopheles gambiae s.s. & 37 & 4 & 2 & 43 & $90.70[82.70-95.21]$ \\
\hline & Anopheles coluzzii & 11 & 11 & 4 & 26 & $63.46[49.87-75.20]$ \\
\hline \multirow[t]{2}{*}{ April-May } & Anopheles gambiae s.s. & 52 & 2 & 2 & 56 & $94.64[88.80-97.52]$ \\
\hline & Anopheles coluzzii & 12 & 16 & 8 & 36 & $55.56[44.09-66.46]$ \\
\hline
\end{tabular}

RR: homozygous resistant; RS: heterozygote; SS: homozygous susceptible; [95\% CI]: 95\% Wilson's confidence interval.

35.37 bites per human per night (interquartile range (IQR): 0.00-42.25) during the four surveys. The mean HBR for all malaria vector species was 121.94 (IQR: 68.50-156.50), 6.98
(IQR: 1.00-8.25), 1.39 (IQR: 0.00-1.00), and 11.15 (IQR: $0.00-9.00)$ bites per human per night in September-October 2016, November-December 2016, February-March 2017 and 
April-May 2017, respectively. According to the count model, the HBR for all malaria vector species varied significantly between surveys $\left(\chi^{2}=1746.8, \mathrm{df}=3, p<0.001\right)$. It was significantly higher in September-October 2016 than in NovemberDecember 2016 (OR [95\% CI] $=23.82$ [18.78, 30.20]), February-March 2017 (OR = 208.60 [155.25, 280.28]), and AprilMay $2017(\mathrm{OR}=28.91$ [22.07, 37.87]).

\section{Biting patterns of malaria vector populations}

More vectors were collected outdoors than indoors (OR $[95 \% \mathrm{CI}]=1.26[1.16-1.37], p<0.001)$, and the outdoor biting rate did not vary significantly between the surveys $\left(\chi^{2}=3.24, \mathrm{df}=3, p=0.3693\right)$. During the four surveys, indoor and outdoor biting activities of An. gambiae s.l. occurred from dusk to dawn. Both indoor and outdoor biting activities of $A n$. gambiae s.l. peaked between 04:00 and 05:00 in SeptemberOctober 2016 and between 02:00 and 03:00 in NovemberDecember 2016 (Fig. 2A and B). In February-March 2017, the majority of indoor and outdoor bites by An. gambiae s.l. occurred between 01:00 and 04:00 and between 03:00 and 04:00, respectively (Fig. 2C). In the April-May 2017 survey, both the indoor and outdoor biting activity curves of An. gambiae s.l. showed a bimodal shape. Indoors, there was one peak between 01:00 and 02:00, and a smaller one between 04:00 and 05:00. Outdoors, there was one peak between 00:00 and 01:00, and a higher one between 04:00 and 05:00 (Fig. 2D). The biting activity profiles of An. gambiae s.l. differed significantly between surveys (Kruskal-Wallis chi-squared $=217.76$, $\mathrm{df}=3, p$-value $<0.001)$, with activity during the first survey (September-October 2016) peaking later than during the other surveys (Dunn Test $p$-values $<0.001$ ).

\section{Infection with $P$. falciparum sporozoites and EIRs}

Plasmodium falciparum sporozoite infection rates per species and surveys are presented in Table 3. The P. falciparum sporozoite rate in malaria vector populations was $7.41 \%$ (95\% IC: 5.47-9.98), 8.98\% (95\% IC: 5.52-14.29), 4.41\% (95\% IC: $1.51-12.18)$, and $1.10 \%$ (95\% IC: $0.06-5.96)$ in September-October 2016, November-December 2016, February-March 2017, and April-May 2017, respectively (Table 3). There were no significant differences in the
$P$. falciparum sporozoite rates between malaria vector species $\left(\chi^{2}=7.5, \mathrm{df}=3, p=0.057\right)$ and surveys $\left(\chi^{2}=4.9, \mathrm{df}=3\right.$, $p=0.179)$. Plasmodium falciparum sporozoite infection rates in malaria vector populations according to location (indoors and outdoors) are presented in Table 4. The P. falciparum sporozoite rates did not differ significantly depending on whether malaria vectors were collected indoors or outdoors $\left(\chi^{2}=0.0796\right.$, df $\left.=1, p=0.78\right)$.

Overall, an unprotected individual living in the Korhogo area was estimated to receive an average of 9.04, 0.63, 0.06 and 0.12 infected bites per night in September-October 2016, November-December 2016, February-March 2017, and April-May 2017, respectively. In September-October 2016, an estimated 0.69 infected bites per night (i.e., 20.7 per month) occurred between 17:00 and 22:00. The average EIR recorded in this study was 2.46 infected bites per person per night.

\section{Frequencies of the $k d r$ and ace-1 alleles}

The frequency of the $k d r$ allele in the An. gambiae s.s. population (frequency range: $90.70-100 \%$ ) was very high throughout the study periods (Table 5). It was significantly higher in September-October 2016 than in February-March 2017 $(p<0.001)$ and April-May $(p<0.001)$. The frequency of the $k d r$ allele in the An. gambiae s.s. population in SeptemberOctober 2016 did not differ from that of November-December 2016 ( $p=1.00)$. The frequency of the $k d r$ allele in the $A n$. coluzzii population ranged from $55.6 \%$ to $100 \%$ during the four surveys (Table 5). It was significantly higher in SeptemberOctober 2016 than in February-March $2017(p<0.001)$ and April-May $2017(p<0.001)$. The frequency of the $k d r$ allele in the An. coluzzii population did not vary significantly between September-October 2016 and November-December 2016 $(p=1.00)$. The $k d r$ allele was more frequent in the An. gambiae s.s. than in the An. coluzzii population $(p<0.001)$. We found significant variations in the frequency of the $k d r$ allele in the An. gambiae s.s. $\left(p<1 \times 10^{-4}\right)$ and An. coluzzii $(p=0.020)$ populations among the six villages. For each survey, genotype frequencies of $k d r$ in the An. gambiae s.s and An. coluzzii populations from each of the six villages were not different from the Hardy-Weinberg expectations $(p>0.05)$.

The ace- 1 frequency in the An. gambiae s.s. population ranged from 15.18 to $30.05 \%$ throughout the study periods (Table 6). The frequency of the ace-1 allele in the An. gambiae s.s. population was significantly higher in September-October

Table 6. Acel mutation frequencies in a subset of Anopheles gambiae s.l.

\begin{tabular}{|c|c|c|c|c|c|c|}
\hline & & RR & $\mathrm{RS}$ & SS & Total & Allelic frequency $(\%)[95 \% \mathrm{CI}]$ \\
\hline \multirow[t]{2}{*}{ September-October } & Anopheles gambiae s.s. & 41 & 156 & 199 & 396 & $30.05[26.96-33.33]$ \\
\hline & Anopheles coluzzii & 0 & 1 & 9 & 10 & $5[0.26-23.61]$ \\
\hline \multirow[t]{2}{*}{ November-December } & Anopheles gambiae s.s. & 15 & 43 & 101 & 159 & $22.96[18.67-27.88]$ \\
\hline & Anopheles coluzzii & 0 & 0 & 5 & 5 & $0[0-27.75]$ \\
\hline \multirow[t]{2}{*}{ February-March } & Anopheles gambiae s.s. & 2 & 12 & 29 & 43 & $18.60[11.79-28.10]$ \\
\hline & Anopheles coluzzii & 0 & 0 & 26 & 26 & $0[0-6.88]$ \\
\hline \multirow[t]{2}{*}{ April-May } & Anopheles gambiae s.s. & 3 & 11 & 42 & 56 & $15.18[9.70-22.97]$ \\
\hline & Anopheles coluzzii & 0 & 1 & 35 & 36 & $1.39[0.07-7.46]$ \\
\hline
\end{tabular}

RR: homozygous resistant; RS: heterozygote; SS: homozygous susceptible; [95\% CI]: 95\% Wilson's confidence interval. 
2016 than in November-December $2016(p=0.021)$, FebruaryMarch $2017(p=0.026)$ and April-May $2017(p<$ 0.001). The frequency of the ace-1 allele in the An. coluzzii population (frequency range: $15.18-30.05 \%$ ) did not vary significantly among the four surveys $(p=0.278)$. The ace-1 allele was significantly more frequent in the An. gambiae s.s. than in An. coluzzii population $\left(p<1 \times 10^{-4}\right)$. The frequency of the ace-1 allele in the An. gambiae s.s. population varied significantly among the six villages $\left(p<1 \times 10^{-4}\right)$. The frequency of the ace-1 allele in the An. coluzzii population did not vary significantly among the six villages $(p=0.211)$. For each survey, genotype frequencies of ace-1 in the An. gambiae and An. coluzzii populations from each of the six villages did not differ from the Hardy-Weinberg proportions $(p>0.05)$.

\section{Discussion}

Anopheles gambiae s.l. is by far the main malaria vector in the Korhogo area, irrespective of the season, but its abundance varied significantly according to the season. The risk of being bitten by malaria vector mosquitoes was found to be up to 200-fold higher in September-October 2016 (rainy season) than in February-March 2017 (dry season). These results are consistent with the bionomics of An. gambiae s.s. Indeed, the breeding habitats of this species are known to increase in number and productivity during the rainy season but almost disappear during the dry season [30]. In September-October 2016 (rainy season), an unprotected individual in the Korhogo area received an estimated nine infected bites per night (i.e., 270 per month). Korhogo is a rural area where several crops including rice are cultivated. Rice paddies are strongly associated with very high densities of malaria vectors [20]. In this study, we found a mean annual EIR of 897.9 infected bites per person per year. Research conducted so far in Africa has reported mean annual EIRs ranging from $<1$ to $>1000$ infected bites per person per year [3]. Therefore, Korhogo ranks at the top level among malaria endemic areas in terms of the intensity of transmission.

Our results revealed that malaria vector populations were significantly exophagic in both the rainy and dry seasons, with no significant difference in outdoor biting rates between seasons. Furthermore, we found that indoor and outdoor biting activities of An. gambiae s.l. peaked later (4-5 am) in September-October 2016 than in the other three surveys. The influence of genetic factors in the biting behaviors of malaria vectors remains poorly understood [26]. However, some studies have shown that Anopheles vectors can adjust their biting behavior in response to a small change in environmental parameters such as temperature [9, 31]. During the four surveys, we recorded environmental data (temperature, humidity, atmospheric pressure, and light intensity) at all the sites during collection. These data would help establish a possible link between environmental variables and the biting behaviors of vectors. It is more and more obvious that LLINs alone are unable to eliminate malaria in high malaria burden countries [19]. In this study, we found that an estimated 0.69 infected bites (i.e., 20.7 per month) occurred daily in September-October 2016 between 17:00 and 22:00 when human populations are potentially unprotected by ITNs. Nonetheless, our results need to be adjusted to the behaviors of the local human populations in terms of sleeping hours, outdoor activities and ITN use in order to more accurately measure human exposure to Plasmodium sp.-infected mosquito bites in the Korhogo area [28]. We will address this research question in another publication using additional data collected in the framework of the REACT project.

Consistent with recent studies carried out in the Korhogo area [6, 24], we found very high frequencies of the $k d r$ mutation in the An. gambiae complex population during the four surveys. The $k d r$ mutation has almost reached fixation in An. gambiaes. $s$. population across Côte d'Ivoire [6]. We identified the ace-1 allele in the An. gambiae complex populations at frequencies ranging from 0 to $30.05 \%$ during the four surveys. A recent study has shown that An. gambiae s.l. mosquitoes from Korhogo are highly resistant to pyrethroids, organochlorides, and carbamates, but susceptible to organophosphates [6]. Accordingly, the use of organophosphates may represent a valuable strategy for the control of this high insecticide resistant vector population. However, this approach would select genotypes bearing ace-1 mutations which display resistance to organophosphates although the ace-1 mutation confers a lower resistance level to organophosphates than carbamates [11]. In our study, we found spatial and temporal variations of the $k d r$ and ace-1 frequencies in the An. gambiae complex population. The frequencies of insecticide resistance alleles in malaria vector populations are known to be influenced by the selective pressures from insecticides used in agriculture and public health, as well as by the fitness costs associated with resistance alleles in the absence of insecticide [1, 10, 23, 27, 40]. Both the $k d r$ and ace-1 alleles were significantly more frequent in the $A n$. gambiae s.s. than in the An. coluzzii population. These differences in $k d r$ and ace- 1 frequencies between An. gambiae s.s. and An. coluzzii have been observed in many areas of Africa $[7,8,12]$.

This study demonstrated that malaria vectors were more likely to feed outdoors than indoors, and the frequencies of the $k d r$ allele were very high in An. gambiae s.l. populations. Moreover, we found that the risk of malaria transmission was significant when people are potentially active. Therefore, malaria transmission would still continue in the Korhogo area even with full coverage of LLINs. A large-scale multi-country study published recently showed conclusively that LLINs are still protective against malaria despite widespread resistance to pyrethroids [22]. However, malaria control in high endemic areas such as Korhogo needs to be strengthened with complementary tools to alleviate the burden of the disease. Therefore, efforts need to be dedicated to evaluating the effectiveness of promising tools to be used in combination with LLINs in high endemic areas. The REACT project will provide data on the impact of four potential strategies on clinical malaria and transmission in two high endemic areas of Burkina-Faso and Côte d'Ivoire. Two of these strategies, i.e., larviciding with Bti and use of ivermectin in cattle and other small ruminants, are in late stages of development, while the two others, i.e., intensive communication for human behavioral changes and indoor residual spraying of insecticide, are already available in the vector control arsenal against malaria. 


\section{Conclusions}

Malaria transmission in the Korhogo area was mainly due to An. gambiae s.s. and An. Coluzzii, while An. funestus group species and An. nili complex species played minor roles. The frequencies of the $k d r$ mutation in the An. gambiae complex population were very high, whereas ace-1 frequencies were moderate. Malaria vectors in Korhogo were more exophagic. The intensity of malaria transmission is extremely high in the Korhogo area, especially during the rainy season. Malaria control in such highly endemic areas needs to be strengthened with complementary tools in order to reduce the burden of the disease.

Acknowledgements. We thank all the mosquito collectors and supervisors for their commitment in the field. We also thank Aboubacar Koné, Akoliba Patrice Azaibou, Youssouf Dosso, Serges Koffi, Koffi Guillaume Konan and Rosine Wolie for their technical assistance.

\section{Conflict of interest}

The authors declare that they have no conflict of interests.

\section{Funding}

This work was part of the REACT project, funded by the French Initiative 5\% - Expertise France (No. 15SANIN213).

\section{Author contributions}

BZ, AAK, NM and CP conceived and designed the study. $\mathrm{BZ}$ oversaw the surveys under the supervision of LPAA, AAK and $\mathrm{CP}$. NM, CP, $\mathrm{AD}$ and $\mathrm{BZ}$ analyzed the data. BZ drafted the manuscript which was revised by the co-authors. All authors read and approved the final manuscript.

\section{Supplementary material}

Supplementary materials are available at https://www. parasite-journal.org/10.1051/parasite/2019040/olm.

\section{References}

1. Awolola TS, Oduola AO, Oyewole IO, Obansa JB, Amajoh CN, Koekemoer LL, Coetzee M. 2007. Dynamics of knockdown pyrethroid insecticide resistance alleles in a field population of Anopheles gambiae s.s. in southwestern Nigeria. Journal of Vector Borne Diseases, 44, 181-188.

2. Bass C, Nikou D, Donnelly MJ, Williamson MS, Ranson H, Ball A, Vontas J, Field LM. 2007. Detection of knockdown resistance (kdr) mutations in Anopheles gambiae: a comparison of two new high-throughput assays with existing methods. Malaria Journal, 6, 111.

3. Beier JC, Killeen GF, Githure JI. 1999. Short report: entomologic inoculation rates and Plasmodium falciparum malaria prevalence in Africa. American Journal of Tropical Medicine and Hygiene, 61, 109-113.
4. Boissière A, Gimonneau G, Tchioffo MT, Abate L, Bayibeki A, Awono-Ambéné PH, Nsango SE, Morlais I. 2013. Application of a qPCR Assay in the investigation of susceptibility to malaria infection of the $\mathrm{m}$ and $\mathrm{s}$ molecular forms of An. gambiae s.s. in Cameroon. PLoS One, 8, e54820.

5. Brooks ME, Kristensen K, van Benthem KJ, Magnusson A, Berg CW, Nielsen A, Skaug HJ, Mächler M, Bolker BM. 2017. glmmTMB balances speed and flexibility among packages for zero-inflated generalized linear mixed modeling. The R Journal, 9(2), 378-400.

6. Camara S, Koffi AA, Ahoua ALP, Koffi K, Kabran J-PK, Koné A, Koffi MF, N'Guessan R, Pennetier C. 2018. Mapping insecticide resistance in Anopheles gambiae (s.l.) from Côte d'Ivoire. Parasites \& Vectors, 11, 19.

7. Dabiré KR, Diabaté A, Namontougou M, Djogbenou L, Kengne P, Simard F, Bass C, Baldet T. 2009. Distribution of insensitive acetylcholinesterase (ace-1R) in Anopheles gambiae s.l. populations from Burkina Faso (West Africa). Tropical Medicine and International Health, 14, 396-403.

8. Dabiré RK, Namountougou M, Diabaté A, Soma DD, Bado J, Toé HK, Bass C, Combary P. 2014. Distribution and frequency of kdr mutations within Anopheles gambiae s.l. populations and first report of the ace.1g119 s mutation in Anopheles arabiensis from Burkina Faso (West Africa). PLoS One, 9, e101484.

9. Dao A, Yaro AS, Diallo M, Timbine S, Huestis DL, Kassogue Y, Traore AI, Sanogo ZL, Samake D, Lehmann T. 2014. Signatures of aestivation and migration in Sahelian malaria mosquito populations. Nature, 516, 387-390.

10. Diabate A, Baldet T, Chandre F, Akogbeto M, Guiguemde TR, Darriet F, Brengues C, Guillet P, Hemingway J, Small GJ, Hougard JM. 2002. The role of agricultural use of insecticides in resistance to pyrethroids in Anopheles gambiae s.l. in Burkina Faso. American Journal of Tropical Medicine and Hygiene, 67, 617-622.

11. Djogbénou L, Weill M, Hougard JM, Raymond M, Akogbéto M, Chandre F. 2007. Characterization of insensitive acetylcholinesterase (ace-1R) in Anopheles gambiae (Diptera: Culicidae): resistance levels and dominance. Journal of Medical Entomology, 44, 805-810.

12. Essandoh J, Yawson AE, Weetman D. 2013. Acetylcholinesterase (Ace-1) target site mutation 119S is strongly diagnostic of carbamate and organophosphate resistance in Anopheles gambiae s.s. and Anopheles coluzzii across southern Ghana. Malaria Journal, 12, 404.

13. Favia G, Lanfrancotti A, Spanos L, Sidén-Kiamos I, Louis C. 2001. Molecular characterization of ribosomal DNA polymorphisms discriminating among chromosomal forms of Anopheles gambiae s.s. Insect Molecular Biology, 10, 19-23.

14. Fornadel CM, Norris LC, Glass GE, Norris DE. 2010. Analysis of Anopheles arabiensis blood feeding behavior in southern Zambia during the two years after introduction of insecticidetreated bed nets. American Journal of Tropical Medicine and Hygiene, 83, 848-853.

15. François R, Jimmy Lopez KB. 2017. Population genetic data analysis using genepop. (R package version 1.0.5).

16. Gillies MT. 1987. A supplement to the Anophelinae of Africa south of the Sahara (Afrotropical Region). Publications of the South African Institute for Medical Research, 55, 1-143.

17. Gillies M, Meillon D. 1968. The Anophelinae of Africa south of the Sahara. Publication of the South African Institute for Medical Research, Johannesburg, 54, 1-343.

18. Goudet J, Raymond M, de Meeüs T, Rousset F. 1996. Testing differentiation in diploid populations. Genetics, 144, 1933-1940.

19. Griffin JT, Hollingsworth TD, Okell LC, Churcher TS, White M, Hinsley W, Bousema T, Drakeley CJ, Ferguson NM, Basáñez M-G, Ghani AC. 2010. Reducing Plasmodium 
falciparum malaria transmission in Africa: a model-based evaluation of intervention strategies. PLoS Medicine, 7, e1000324.

20. Ijumba JN, Lindsay SW. 2001. Impact of irrigation on malaria in Africa: paddies paradox. Medical and Veterinary Entomology, 15, 1-11.

21. Killeen GF. 2014. Characterizing, controlling and eliminating residual malaria transmission. Malaria Journal, 13, 330.

22. Kleinschmidt I, Bradley J, Knox TB, Mnzava AP, Kafy HT, Mbogo C, Ismail BA, Bigoga JD, Adechoubou A, Raghavendra K, Cook J, Malik EM, Nkuni ZJ, Macdonald M, Bayoh N, Ochomo E, Fondjo E, Awono-Ambene HP, Etang J, Akogbeto M, Bhatt RM, Chourasia MK, Swain DK, Kinyari T, Subramaniam K, Massougbodji A, Okê-Sopoh M, Ogouyemi-Hounto A, Kouambeng C, Abdin MS, West P, Elmardi K, Cornelie S, Corbel V, Valecha N, Mathenge E, Kamau L, Lines J, Donnelly MJ. 2018. Implications of insecticide resistance for malaria vector control with long-lasting insecticidal nets: a WHOcoordinated, prospective, international, observational cohort study. Lancet Infectious Diseases, 18, 640-649.

23. Kliot A, Ghanim M. 2012. Fitness costs associated with insecticide resistance. Pest Management Science, 68, 14311437.

24. Koffi AA, Ahoua Alou LP, Kabran JPK, N'Guessan R, Pennetier C. 2013. Re-visiting insecticide resistance status in Anopheles gambiae from Côte d'Ivoire: a nation-wide informative survey. PLoS One, 8, 1-10.

25. Livak KJ. 1984. Organization and mapping of a sequence on the Drosophila melanogaster $\mathrm{X}$ and $\mathrm{Y}$ chromosomes that is transcribed during spermatogenesis. Genetics, 107, 611-634.

26. Maliti DV, Marsden CD, Main BJ, Govella NJ, Yamasaki Y, Collier TC, Kreppel K, Chiu JC, Lanzaro GC, Ferguson HM, Lee Y. 2016. Investigating associations between biting time in the malaria vector Anopheles arabiensis Patton and single nucleotide polymorphisms in circadian clock genes: support for sub-structure among An. arabiensis in the Kilombero valley of Tanzania. Parasites \& Vectors, 9, 109.

27. Mathias DK, Ochomo E, Atieli F, Ombok M, Nabie Bayoh M, Olang G, Muhia D, Kamau L, Vulule JM, Hamel MJ, Hawley WA, Walker ED, Gimnig JE. 2011. Spatial and temporal variation in the kdr allele L1014S in Anopheles gambiae s.s. and phenotypic variability in susceptibility to insecticides in Western Kenya. Malaria Journal, 10, 10.

28. Moiroux N, Damien GB, Egrot M, Djenontin A, Chandre F, Corbel V, Killeen GF, Pennetier C. 2014. Human exposure to early morning Anopheles funestus biting behavior and personal protection provided by long-lasting insecticidal nets. PLoS One, 9, e104967.

29. Moiroux N, Gomez MB, Pennetier C, Elanga E, Djènontin A, Chandre F, Djègbé I, Guis H, Corbel V. 2012. Changes in Anopheles funestus biting behavior following universal coverage of long-lasting insecticidal nets in Benin. Journal of Infectious Diseases, 206, 1622-1629.

30. Mourou J-R, Coffinet T, Jarjaval F, Cotteaux C, Pradines E, Godefroy L, Kombila M, Pagès F. 2012. Malaria transmission in Libreville: results of a one year survey. Malaria Journal, 11, 40.

31. Ngowo HS, Kaindoa EW, Matthiopoulos J, Ferguson HM, Okumu FO. 2017. Variations in household microclimate affect outdoor-biting behaviour of malaria vectors. Wellcome Open Research, 2, 102.
32. Ojuka P, Boum Y, Denoeud-Ndam L, Nabasumba C, Muller Y, Okia M, Mwanga-Amumpaire J, De Beaudrap P, Protopopoff N, Etard JF. 2015. Early biting and insecticide resistance in the malaria vector Anopheles might compromise the effectiveness of vector control intervention in Southwestern Uganda. Malaria Journal, 14, 1-8.

33. PNLP: Programme National de Lutte Contre le Paludisme en Côte d'Ivoire. 2014. Plan stratégique national de lutte contre le paludisme 2012-2015 (période replanifiée 2014-2017). Approche stratifiée de mise à l'échelle des interventions de lutte contre le paludisme en Côte d'Ivoire et consolidation des acquis. Abidjan: Ministère de La Santé et l'Hygiène Publique. $149 \mathrm{p}$.

34. Raymond MRF. 1995. GENEPOP Version 1.2. A population genetics software for exact tests and ecumenicism. Journal of Heredity, 26, 248-249.

35. Robert V, Macintyre K, Keating J, Trape JF, Duchemin JB, Warren M, Beier JC. 2003. Malaria transmission in urban subsaharian Africa. American Journal of Tropical Medicine and Hygiene, 68, 169-176.

36. Sadia-Kacou CMA, Alou LPA, Edi AVC, Yobo CM, Adja MA, Ouattara AF, Malone D, Koffi AA, Tano Y, Koudou BG. 2017. Presence of susceptible wild strains of Anopheles gambiae in a large industrial palm farm located in Aboisso, South-Eastern of Côte d'Ivoire. Malaria Journal, 16, 157.

37. Scott JA, Brogdon WG, Collins FH. 1993. Identification of single specimens of the Anopheles gambiae complex by the polymerase chain reaction. American Journal of Tropical Medicine and Hygiene, 49, 520-529.

38. Sinka ME, Bangs MJ, Manguin S, Rubio-Palis Y, Chareonviriyaphap T, Coetzee M, Mbogo CM, Hemingway J, Patil AP, Temperley WH, Gething PW, Kabaria CW, Burkot TR, Harbach RE, Hay SI. 2012. A global map of dominant malaria vectors. Parasites \& Vectors, 5, 69.

39. Trape JF, Tall A, Sokhna C, Ly AB, Diagne N, Ndiath O, Mazenot C, Richard V, Badiane A, Dieye-Ba F, Faye J, Ndiaye $\mathrm{G}$, Diene Sarr F, Roucher C, Bouganali C, Bassène H, TouréBaldé A, Roussilhon C, Perraut R, Spiegel A, Sarthou JL, da Silva LP, Mercereau-Puijalon O, Druilhe P, Rogier C. 2014. The rise and fall of malaria in a west African rural community, Dielmo, Senegal, from 1990 to 2012: a 22 year longitudinal study. Lancet Infectious Diseases, 14, 476-488.

40. Verhaeghen K, Van Bortel W, Roelants P, Okello PE, Talisuna A, Coosemans M. 2010. Spatio-temporal patterns in $\mathrm{kdr}$ frequency in permethrin and DDT resistant Anopheles gambiae s.s. from Uganda. American Journal of Tropical Medicine and Hygiene, 82, 566-573.

41. WHO. 2018. World Malaria Report 2018. Geneva: World Health Organization.

42. Zogo B, Soma DD, Tchiekoi BN, Somé A, Alou LPA, Koffi AA, Fournet F, Dahounto A, Coulibaly B, Kandé S, Dabiré RK, Baba-Moussa L, Moiroux N, Pennetier C. 2019. Anopheles bionomics, insecticide resistance mechanisms and malaria transmission in the Korhogo area, northern Côte d'Ivoire: a pre-intervention study. BioRxiv, 589556.

43. Zoh DD, Ahoua Alou LP, Toure M, Pennetier C, Camara S, Traore DF, Koffi AA, Adja AM, Yapi A, Chandre F. 2018. The current insecticide resistance status of Anopheles gambiae (s.l.) (Culicidae) in rural and urban areas of Bouaké, Côte d'Ivoire. Parasites \& Vectors, 11, 118.

Cite this article as: Zogo B, Soma DD, Tchiekoi BN, Somé A, Ahoua Alou LP, Koffi AA, Fournet F, Dahounto A, Coulibaly B, Kandé S, Dabiré RK, Baba-Moussa L, Moiroux N Pennetier C. 2019. Anopheles bionomics, insecticide resistance mechanisms, and malaria transmission in the Korhogo area, northern Côte d'Ivoire: a pre-intervention study. Parasite 26, 40. 
Reviews, articles and short notes may be submitted. Fields include, but are not limited to: general, medical and veterinary parasitology; morphology, including ultrastructure; parasite systematics, including entomology, acarology, helminthology and protistology, and molecular analyses; molecular biology and biochemistry; immunology of parasitic diseases; host-parasite relationships; ecology and life history of parasites; epidemiology; therapeutics; new diagnostic tools.

All papers in Parasite are published in English. Manuscripts should have a broad interest and must not have been published or submitted elsewhere. No limit is imposed on the length of manuscripts.

Parasite (open-access) continues Parasite (print and online editions, 1994-2012) and Annales de Parasitologie Humaine et Comparée (1923-1993) and is the official journal of the Société Française de Parasitologie. 